\title{
PENYULUHAN PENDIDIKAN KARAKTER KEPADA PARA GURU SMP KOTA BEKASI
}

\author{
Lusiana Wulansari ${ }^{1}$, Maria Cleopara ${ }^{2}$, Sara Sahrazad ${ }^{3}$, Lidya Natalia Sartono ${ }^{4}$, Sigit \\ Widiyarto $^{5}$ \\ ${ }^{1,3)}$ Program Studi Bmbingan Konseling, FIPPS, Universitas Indraprasta PGRI Jakarta \\ ${ }^{2,4)}$ Program Studi Informatika, FTIK, Universitas Indraprasta PGRI Jakarta \\ ${ }^{5}$ ) Program Studi Pendidikan Ekonomi, FIPPS, Universitas Indraprasta PGRI Jakarta \\ e-mail: lusianawulansari@gmail.com,mariacleopatra1313@gmail.com, sara.sahrazad@gmail.com, \\ lidyanataliasartono@gmail.com, sigit.widiyanto372@gmail.com
}

\begin{abstract}
Abstrak
Karakter merupakan nilai- nilai kebajikan yang harus dipunyai oleh para siswa, agar dapat mencapai tujuan idupnya kelak. Penyuluhan ini dirasakan penting, sebab masih banyak karakter menyimpang yang dilakukan oleh anak dibawah umur. Baik itu nilai - nilai kesusilaan dan moral. Tujuan penyuluhan ini, untuk meningkatkan dan memperkuat pola pendidikan karakter pada guru SMP. Pendidikan karakter ini akan di ajarkan kepada para siswa SMP. Metode pelaksanaan yang digunakan adalah metode tanya jawab dan presentasi serta pendampingan. Kegiatan ini diikuti oleh 16 guru bidang studi dan staf tata usaha sebanyak 4 orang. Kegiatan dilakukan dengan "new normal" dimana diterapkan "protocol " kesehatan yang ketat, agar pelaksanaan berjalan dengan baik dan aman. Kegiatan pengabdian kepada masyarakat ini berlangsung dari bulan Agustus sampai dengan Nopember 2020. Hasil kegiatan menunjukkan bahwa para guru dapat memahami pola pengajaran karakter, dan dapat melaksanakan metode dengan baik. Pola pengajaran yang bertumpu pada karakter, maka para siswa mau mencontoh kepada para guru.
\end{abstract}

Kata Kunci : Penyuluhan, Pendidikan, Karakter.

\begin{abstract}
Character are the virtues that must be possessed by students, in order to achieve their future life goals. This counseling is felt to be important, because there are still many deviant characters carried out by minors. Whether it's ethical and moral values. The purpose of this counseling is to improve and strengthen character education patterns for junior high school teachers. This character education will be taught to junior high school students. The implementation method used is the question and answer method and presentation and mentoring. This activity was attended by 16 subject teachers and 4 administrative staff. Activities are carried out with a "new normal" in which a strict health "protocol" is applied, so that implementation runs well and safely. This community service activity takes place from August to November 2020. The results of the activity show that teachers can understand the character teaching patterns, and can implement the method well.
\end{abstract}

Keywords: Counseling, Education, Character.

\section{PENDAHULUAN}

Indonesia adalah negara yang menjunjung tinggi nilai - nilai kebeneran dan karakter yang berbudi luhur . Untuk itulah Indonesia memerlukan insan manusia yang berkarakter, berkompetitif serta menguasi ilmu pengetahuan dan teknologi serta tidak mengabaikan aspek dasar nilai keagamaan supaya dapat menghasilkan produk dengan kualitas-kualitas yang lebih baik. Untuk memenuhi sumberdaya manusia tersebut, pendidikan memiliki peran yang sangat penting. Hal ini sesuai dengan UU No 20 Tahun 2003 Tentang Sistem Pendidikan Nasional pada Pasal 3, yang menyebutkan bahwa "Pendidikan nasional berfungsi mengembangkan kemampuan dan membentuk karakter serta peradaban bangsa yang bermartabat dalam rangka mencerdaskan kehidupan bangsa”. Pendidikan merupakan salah satu proses dalam membentuk, mengarahkan dan mengembangkan kepribadian serta kemampuan seseorang. Pendidikan yang baik dan berkualtias juga turut menentukan pembelajaran karakter itu sendiri. Untuk busa mencapai pribadi yang 
bermoral, salah satu cara yang dapat di lakukan adalah memberikan pembelajaran secara efektif, efisien, dan menarik atau dalam bahasa sekarang disebut dengan PAIKEM (Praktis, Aktif, Inovatif, Kreatif, dan Menyenangkan) untuk dapat mencapai pembelajaran karakter yang berkua-litas, perlu dirancang strategi yang inovatif (Maunah, B. (2015). Pada 2500 tahun yang lalu Socrates dalam buku Anasufi Banawi, mengatakan tujuan yang melandasi dari pendidikan adalah untuk membuat seseorang menjadi baik dan cerdas. Manusia yang terdidik seharusnya menjadi orang bijak, yaitu orang yang dapat menggunakan ilmunya untuk hal-hal yang baik (beramal sholeh) dan dapat hidup secara bijak dalam seluruh aspek kehidupan keluarga, bertetangga, bermasyarakat dan bernegara. Karenanya sebuah sistem pendidikan yang berhasil adalah yang dapat membentuk manusiamanusia berkarakter yang sangat diperlukan dalam mewujudkan sebuah negara kebangsaan terhormat. Pendidikan karakter merupakan bentuk kegiatan manusia yang di dalamnya terdapat suatu tindakan yang mendidik diperuntukkan bagi generasi selanjutnya. Tujuan pendidikan karakter adalah untuk membentuk penyempurnaan diri individu secara terus-menerus dan melatih kemampuan diri demi menuju kearah hidup yang lebih baik.

Selanjutnya karakter itu sendiri merupakan nilai-nilai perilaku manusia yang berhubungan dengan Tuhan Yang Maha Esa, diri sendiri, sesama manusia, lingkungan, dan kebangsaan yang terwujud dalam pikiran, sikap, perasaan, perkataan, dan perbuatan berdasarkan norma-norma agama, hukum, tata krama, budaya, dan adat istiadat. Pendidikan karakter dapat diterapkan dalam pembelajaran pada setiap mata pelajaran. Materi pembelajaran yang berkaitan dengan norma atau nilai-nilai pada setiap mata pelajaran perlu dikembangkan, dieksplisitkan, dikaitkan dengan konteks kehidupan sehari-hari. Dengan demikian, pembelajaran nilai-nilai karakter tidak hanya pada tataran kognitif, tetapi menyentuh pada internalisasi, dan pengamalan nyata dalam kehidupan peserta didik sehari-hari di masyarakat. Pendidikan karakter di sekolah sangat terkait dengan manajemen atau pengelolaan sekolah. Pengelolaan yang dimaksud adalah bagaimana pendidikan karakter direncanakan, dilaksanakan, dan dikendalikan dalam kegiatan-kegiatan pendidikan di sekolah secara memadai. Pengelolaan tersebut antara lain meliputi, nilai-nilai yang perlu ditanamkan, muatan kurikulum, pembelajaran, penilaian, pendidik dan tenaga kependidikan, dan komponen terkait lainnya. Dengan demikian, manajemen sekolah merupakan salah satu media yang efektif dalam pendidikan karakter di sekolah.

Dewasa ini masyarakat menuntut peningkatan intensitas dan kualitas pelaksanaan pendidikan karakter pada lembaga pendidikan formal. Tuntutan tersebut didasarkan pada fenomena sosial yang berkembang, yakni meningkatnya kenakalan remaja dalam masyarakat, seperti perkelahian massal dan berbagai kasus dekadensi moral lainnya. Bahkan di kota-kota besar tertentu, gejala tersebut telah sampai pada taraf yang sangat meresahkan. Oleh karena itu, lembaga pendidikan formal sebagai wadah resmi pembinaan generasi muda diharapkan dapat meningkatkan peranannya dalam pembentukan kepribadian peserta didik melalui peningkatan intensitas dan kualitas pendidikan karakter. Akan tetapi sekolah yang menjadi harapan dalam penanaman nilai-nilai ternyata belum mampu melakukan itu secara optimal.

Masalah lain yang tengah dihadapi oleh bangsa Indonesia adalah sistem pendidikan dini yang ada sekarang ini terlalu berorientasi pada pengembangan otak kiri (kognitif) dan kurang memperhatikan pengembangan otak kanan (afektif, dan empati). Padahal, pengembangan karakter lebih berkaitan dengan optimalisasi fungsi otak kanan. Mata pelajaran yang berkaitan dengan pendidikan karakter pun (seperti budi pekerti dan agama) ternyata pada prakteknya lebih menekankan pada aspek otak kiri (hafalan). Pembentukan karakter harus dilakukan secara sistematis dan berkesinambungan yang melibatkan aspek "knowledge, feeling, loving, dan acting". Pada dasarnya, anak yang kualitas karakternya rendah adalah anak yang tingkat perkembangan emosi-sosialnya rendah, sehingga anak beresiko besar mengalami kesulitan dalam belajar, berinteraksi sosial, dan tidak mampu mengontrol diri. Berbagai masalah bangsa Indonesia di berbagai bidang selama ini tidak lepas dari karakter dan nilai-nilai masyarakat. Kalau saat ini banyak kritik yang terkait dengan karakter bangsa, maka sekolah sebagai salah satu lembaga pendidikan, ikut bertanggung jawab untuk mengatasi permasalahan tersebut. "Banyak orang berpandangan bahwa kondisi demikian diduga bermula dari apa yang dihasilkan oleh dunia pendidikan. Pendidikanlah yang sesungguhnya paling besar memberikan kontribusi terhadap situasi ini" (Akhmad Sudrajat, 2010). Anak-anak yang telah melewati sistem pendidikan selama 
ini, mulai dari pendidikan sekolah kurang memiliki kemampuan mengelola konflik dan kekacauan, sehingga anak-anak dan remaja selalu menjadi korban konflik dari kekacauan tersebut

\section{METODE}

Kegiatan ini menggunakan metode penyuluhan tatap muka berbasis protokol kesehatan, pemberian materi, praktek dan pendampingan, serta evaluasi tiap semester. Kegiatan berlangsung pada bulan Agustus sampai dengan Oktober 2020, di SMP Yadika 5 Jakarta Barat. Adapun jadwal dan materi penyuluhan sebagai berikut :

Tabel. 1. Materi Penyuluhan

\begin{tabular}{lll}
\hline No & \multicolumn{1}{c}{ Materi } & Keterangan \\
\hline & $\begin{array}{l}\text { Integrasi } \\
\text { Pendidikan } \\
\text { Karakter }\end{array}$ & 60 Menit \\
\hline $\begin{array}{l}\text { Muatan Pendidikan } \\
\text { karakter }\end{array}$ & 90 Menit \\
\hline Aplikasi karakter & 60 menit \\
\hline tanya jawab & 60 menit \\
\hline
\end{tabular}

Kegiatan penyuluhan dilaksanakan dengan melibatkan masyarakat ,dan berkoordisasi dengan keluruhan setempat, karena kegiatan harus melalui izin. Hal ini dilakukan agar, pihak sekolah selalu terjaga dari virus corona. Tim menggunakan masker dan alat alat pelindung diri seperti , hand sanitizer dan lain - lain.

\section{HASIL DAN PEMBAHASAN}

Pada kegiatan pengabdian kepada masyarakat, setelah mendapat izin dari pengurus $\mathrm{RT} / \mathrm{Rw}$ setempat, tim melakukan berbagai persiapan, seperti menyiapkan alat infokus, hand out dan beberapa video yang akan ditayangkan oleh tim kepada para guru dan staff TU.

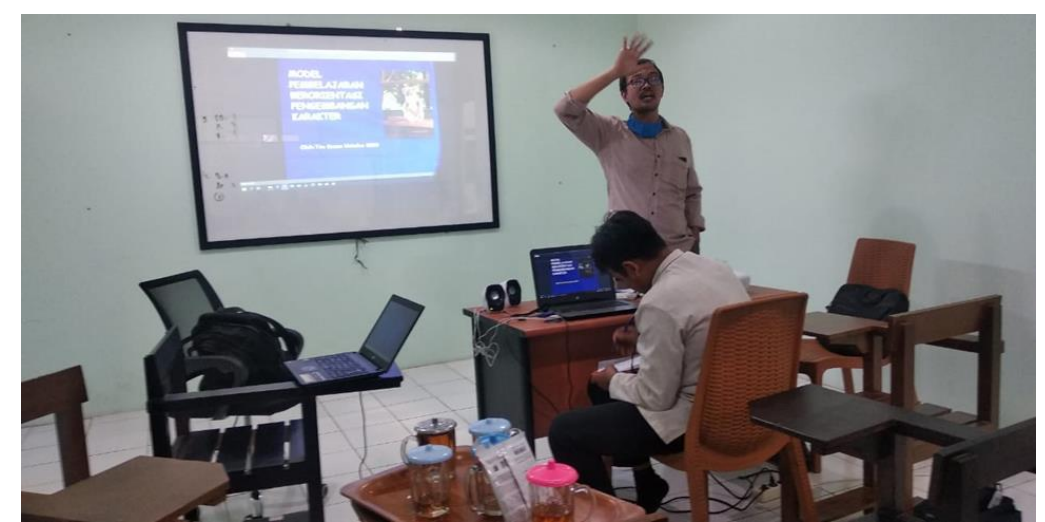

Gambar . 1. Tim sedang memaparkan materi pembelajaran karakter.

Pelaksanaan penyuluhan materi sesi 1, 2 dan 3 berjalan dengan lancer. Para guru diberikan kesempatan untuk bertanya, adapau pertanyaan yang dapat dirangkum oleh tim adalah sebagai berikut :

Metode apa yang baik dalam penerapak karakter pada siswa nanti, kedua, bagaimana memantau perkembangan karakter siswa, agar para orang tua dan guru selalu dapat mengawasi pertanyaan ketiga, berikan contoh nyata, bagaiman menangani siswa yang berkarakter kurang terpuji. 
Beberapa pertanyaan lain ,masih ada, namun secara umum, ke 3 pertanyaan tersebut paling dominan ditanya oleh para guru dan staff TU. Tim menjawab pola pengajaran karakter dan memberikan contoh nyata pembelajaran karakter dengan baik. Diantaranya tim menjelaskan bahwa implementasi pendidikan nilai. Berkenaan dengan keteladanan. Pengimplementasian pendidikan nilai kepada peserta didik memerlukan adanya kesadaran para pendidik agar senantiasa menjadi contoh bagi peserta didik agar tidak bersikap mendua. Misalnya, jika peserta didik dituntut berperilaku jujur, berucap dengan upacan yang baik, konsekuensinya para pendidik dituntut berperilaku jujur, tidak mengajarkan kebohongan, dan bertutur kata yang baik.Sebagai konsekuensinya, para pendidik (orang tua, guru, dan para pembimbing) harus konsisten dalam berperilaku moral karena peserta didik tumbuh dan berkembang mengikuti model perilaku para pendidik. Mereka akan melakukan apa yang dilakukan dan dikatakan oleh si pendidik. Para pendidik hendaknya selalu memelihara nilai diajarkan dan konsisten dalam berperilaku. Keluarga pada hakikatnya merupakan wadah pembentukan karakter masing-masing anggotanya, terutama anak-anak yang masih berada dalam bimbingan dan tanggung jawab orang tuanya ( Sukiyani, F. : 2014).

\section{SIMPULAN}

Pembelajaran karakter sangat strategis dilaksanakan. Hal ini terbukti banyak keluhan para orang tua yang masih banyak, karakter siswa yang belum optimal. Kegaitan ini hars dibarengi oleh karakter para guru yang baik, sebagai "role model", sehingga murid dapat mencontoh . Para orang tua juga harus membantu pembentukan karaktr para siswa, agar siswa merasa diperhatikan dan selalu membiasakan karakter dirumah maupun disekolah.

\section{SARAN}

Para guru sebaiknya memberikan suri tauladan yang baik dalam pembelajaran di kelas. Materi yang diberikan dapat disisipkan dengan nilai - nilai pendidikan karakter, sehingg para siswa menjadi insan yang berbudi luhur.

\section{DAFTAR PUSTAKA}

Ati, A. P., Cleopatra, M., \& Widiyarto, S. (2020). Strategi Pembelajaran dan Pengajaran Menulis Bahasa Indonesia: Tantangan di Era Revolusi Industri 4.0. PROSIDING SAMASTA.

Sukiyani, F. (2014). Pendidikan Karakter dalam Lingkungan Keluarga. SOCIA: Jurnal Ilmu-Ilmu Sosial, 11(1).

Sunarmintyastuti, L., Suprapto, H. A., Sandiar, L., Leksono, A. W., \& Widiyarto, S. (2020). Penyuluhan Kewirausahaan Dan Pemberdayaan Siswa Yatim Piatu Di Ciputat Tangerang Selatan Banten. Abidumasy Jurnal Pengabdian Kepada Masyarakat, 1(2), 2429.

Sunarmintyastuti, L., \& Suprapto, H. A. (2020). Pengembangan SDM Melalui Minat dan Motivasi Santriwati pada Yayasan Taufidzul Qur'an Ar-Rahmani di Ciputat Tangerang Selatan. JURNAL ILMIAH WAHANA PENDIDIKAN, 6(2), 104-109.

Supandi, A., Sahrazad, S., Wibowo, A. N., \& Widiyarto, S. (2020). Analisis Kompetensi Guru: Pembelajaran Revolusi Industri 4.0. PROSIDING SAMASTA.

Hadi, S., Puspita, F., Ati, A. P., \& Widiyarto, S. (2020). Penyuluhan Dan Pembelajaran Karakter Melalui Pelaksanaan Idul Adha Pada Siswa Sma. Jurnal Pemberdayaan: Publikasi Hasil Pengabdian Kepada Masyarakat, 4(2), 205-210.

Maunah, B. (2015). Implementasi pendidikan karakter dalam pembentukan kepribadian holistik siswa. Jurnal Pendidikan Karakter, (1).

Sunarmintyastuti, L., Suprapto, H. A., Sandiar, L., Leksono, A. W., \& Widiyarto, S. (2020). PENYULUHAN KEWIRAUSAHAAN DAN PEMBERDAYAAN SISWA YATIM PIATU DI CIPUTAT TANGERANG SELATAN BANTEN. ABIDUMASY Jurnal Pengabdian Kepada Masyarakat, 1(2), 24-29.

Suprapto, H. A. (2018). PELATIHAN Pembuatan Proposal Rencana Bisnis (Business 
Plan) Bagi Siswa Madrasah Tsanawiyah Nurul Hikmah Dan Smp Al-Ihsan Guna Meningkatkan Kemampuan Berwirausaha. Abdimas Siliwangi, 1(2), 81-88.

Vernia, D. M., Widiyarto, S., Wulansari, L., \& Rusdi, M. (2018). Penyuluhan Dalam Meningkatkan Partisipasi Program Dana Desa. Prosiding Sembadha, 1(1), 72-78.

Vernia, D. M., Widiyarto, S., Narsih, D., \& Tiwinyanti, L. (2020). Sosialisasi Dan Pembekalan Strategi Pemasaran Produk Olahan Pisang Pada Siswa Pondok. Jurnal Pengabdian UntukMu NegeRI, 4(1), 125-128.

Widiyarto, S., Wulansari, L., \& Hasanusi, F. S. (2020). Pelatihan "English Communicative" Guna Mempersiapkan SDM Berkualitas dan "Competitive". Intervensi Komunitas, 1(2), 125-131.

Widiyarto, S., Narsih, D., Ati, A. P., Vernia, D. M., \& Alifah, S. (2020). Pelatihan Pajak PPh 21 Dalam Rangka Membangun Kesadaran Pajak Pada Siswa SMK Bangun Persada Bekasi. Intervensi Komunitas, 2(1)

Zakaria ,Y.(2010 ) Peningkatan Proses Belajar Siswa Melalui Model Pembelajaran Sea Digital Class Menggunakan Edmodo Dan Webex (Studi Kasus : Smk Informatika AlIrsyad,Skripsi Sekolah tinggi Informasi dan manajam 